\title{
Order to Dispense
}

National Cancer Institute

\section{Source}

National Cancer Institute. Order to Dispense. NCI Thesaurus. Code C154534.

A prescription drug order that specifies outpatient dispensing of the drug. 